\title{
Dynamics of Oil Receipts, Health Expenditure and Health Quality in Nigeria
}

\author{
Mathew ADAGUNODO Rasheed OYAROMADE* \\ Department of Economics, Osun State University, Osun State, Nigeria \\ * E-mail of the corresponding author: rasheed.oyaromade@uniosun.edu.ng
}

\begin{abstract}
The determinant of health status has received an extensive attention in the literature for a large number of studies across the world. Empirical studies have explored the relationship between health expenditure and health status; however, the dynamic relationship amongst oil receipts, health expenditure and health quality is an empirical issue that has received little attention particularly in Nigeria. This study investigated the tripartite relationship among oil receipts, health expenditure on health status in Nigeria using pairwise granger causality test and autoregressive distributive lag approach (ARDL). The study shows that unidirectional causality runs from oil receipts to health expenditure and health quality. There is also bidirectional causality between health expenditure and health quality. The cointegration result revealed there is long run relationship among these variables. This study also found that oil revenue and health expenditure have negative and significant impact on child mortality rate but positive and significant effect on life expectancy. This finding obviously would facilitate the policies that will improve health sector in Nigeria.
\end{abstract}

Keywords: Oil Receipts, Health Expenditure, Health Quality, Granger Causality, ARDL, Nigeria

DOI: $10.7176 / J R D M / 67-06$

Publication date:July $31^{\text {st }} 2020$

\section{Introduction}

Oil is not only a major global energy source but also the mainstay of the economy in oil exporting countries. The Nigeria's economic policies and growth have been greatly influenced by oil sector for more than five decades. Since the global energy crisis of 1972/73, the petroleum subsector of the Nigerian economy has become the most important source of revenue and foreign exchange earnings. Nigerian petroleum sector as the engine of growth drives the entire Nigerian economy and society (Iwayemi, 2001). However, there is a disparity between oil receipts and health sector performance. Despite huge receipts from oil, Nigeria is still regarded as a poor country due to inability to adequately meet basic needs of life for a large part of its population including access to good health. The divergence that has been observed between oil receipts and developmental level in the health sector contradicts the theoretical postulation that the presence of abundant natural resource helps the developing nation to overcome the challenges of capital shortfalls and provide required resources for the attainment of sustainable development goals. Also, Revenue Spending Hypothesis as argued by Friedman (1978), and Buchanan and Wagner (1978) indicate that government expenditures are heavily affected by revenues, as most of the government expenditures are financed by revenues. A fluctuation in revenues will, therefore, lead to fluctuations in the implementation of government spending programmes.

In recent years, fluctuations of oil receipts and global health pandemic have made oil-health expenditures a pressing issue in Nigeria due to its implications on health outcomes. There is assertion that underlines the positive impact of revenue on government spending but health expenditure in oil producing countries is still far below $15 \%$ of annual budgetary allocation as recommended by World Health Organisation (WHO). This raises controversy on whether health spending really have robust effect on health outcome in oil producing countries especially Nigeria or not. Also, there is claim that good health enables better earning ability for both workers and enterprises which in turn enhance the tax base of the government leading to better fiscal posture. These interactions, all things being equal, will lead to good standard of living (Babatunde 2012). It is also observed that revenue constraints hinder public expenditures especially in resources rich countries. Thus, oil revenues create a significant dependency for oil-exporting countries, which have a further impact on government spending on health services and health quality.

Several studies have examined the relationship between oil and macroeconomic performance (Boye 2001; Olomola \&Adejumo2006; Eltony, and Al-Awadi, 2001; Akinlo 2012; Dizaji, 2014; Rahma et al. 2016), but one of the most relevant fundamental issue is the fiscal side of the economy. Numerous studies have examined the asymmetric and non-asymmetric effect of oil on government expenditures, as one of the characteristic features of oil exporting economies (Hamdi and Sbia 2013; Ahmad and Masan, 2015; Aregbeyen, and Kolawole, 2015; 
Farzanegan and Markwardt 2009; Lorde et al. 2009; Ebrahim and Mohammad 2012), however literature on oil receipt and health expenditure nexus in Nigeria is scanty. Realizing the importance of health quality and its contribution to the national economy, researchers have been conducting studies to explore the relationship between health expenditure and health outcomes for decades. However, most of these studies are based on developed countries (see, for example, Elola, Daponte, and Navarro 1995; Becchetti, Conzo and Salustri 2017; Kim and Lane 2013; Day and Tousignant 2005) but such studies on developing countries are limited. Most of the studies on developing countries focused on health-growth nexus (Olaniyan, Onisanwa, and Oyinlola, 2013; Odubunmi, Saka and Oke 2012; Babatunde, 2012; Mohsen and Maysam 2011; Mekdem 2012). Several studies have also analysed the determinants of health status in Nigeria (Agbatogun and Taiwo 2010; Kamiya, 2010; Abbas, and Hiemenz, 2011; Tang, 2010), but only few studies investigate health expenditure and health quality relationship (Edeme , Emecheta, and Omeje 2017; Nwanosikeb, Orji, Okafor and Umesiobi 2015; Matthew, Adegboye, and Fasina 2015; Yaqub, Ojapinwa and Yussuff 2013). The fact that findings in the literature are mixed and inconclusive has necessitated the present study. Moreover, the studies on the dynamic relationship between oil receipts, health expenditures and health quality are still controversial and unsatisfactory, this call for further empirical investigation.

This paper is motivated by these two gaps in the literature: First, many studies investigate the relationship between oil price shocks and other variables, however there is paucity in the literature of the studies that examine the tripartite relationship among oil receipt, health expenditures and health outcomes. Also, the fact that some of these studies have been done long ago and recent development in the sector makes a new study in this area very imperative. Second, the findings on relationship between health expenditure and health outcomes, oil receipts and health expenditure are mixed and inconclusive. This calls for further studies on tripartite relationship among oil receipts, health expenditures and health outcomes in Nigeria. The paper is organized as follows; Section two features conceptual, theoretical and empirical review. Methods, data and measurement are presented in section three, section four contains empirical results and discussion and section five concludes the study.

\section{Conceptual, Theoretical and Empirical Review}

Over the past years, a great deal of theoretical studies has been developed to explain the relationship among various macroeconomic performances and fiscal policy instruments. Aside the intervention made by Keynes on the importance of the visible hand of government to correct market failures and externalities of the free market enterprises, different fundamental questions about economic behaviour have been raised under different hypotheses to show various macroeconomic implications. Among these hypotheses are: the conventional view of debt; Ricardian equivalence theorem and tax-smoothing models. Under the conventional view of debt, it was proposed that the most important effects of government budget deficits is that it increases aggregate demand in the short-run, and reduces capital stock in long-run. In the same vein, government debt reduces national savings, which in turn crowds out capital accumulation (Mankiw, 2000). The Ricardian equivalence theorem proposition is that policy will not alter consumption, capital accumulation, or growth. The situation with the tax cut and budget deficit is equivalent to the situation without it. However, the overall conclusion of the theorem states that policy does not influence savings or capital accumulation but only the quantity of government purchases regardless of how it is being financed i.e. taxation or borrowing. And, the tax smoothing models states that what determines the deficit is the desire of government to minimize distortions associated with raising taxes (Barro, 1979), implying that deficits and surpluses arise when the ratio of government purchases to output is expected to change.

Odubunmi et al. (2012) examine the co-integrating relationship between health expenditure, health outcomes and economic growth in Nigeria. Their study intelligently incorporated other variables such as population growth rate and foreign aids as mediating variables. Their empirical result supports the existence of a significant negative relationship between economic growth and health expenditure in Nigeria. Becchetti, Conzo and Salustri (2017) investigated the impact of health expenditure on health outcomes on a large sample of Europeans aged above 50 using individual and regional-level data. The results showed that health expenditure to GDP and health expenditure per capita have a negative and significant impact on changes in the number of chronic diseases. Boachie and Ramu (2015) adopted the OLS and Newey-west estimation techniques to examine the impact of public health spending on health status for the period 1990-2012. It was revealed that the declining or falling infant mortality rate in Ghana has been influenced by public health spending among other factors.

Kulkarni (2016) used the panel data regression with fixed effects model to examine the differences in the health care systems of Brazil, India, China, Russian Federation and South Africa, the emerging economies of BRICS. The results show a positive relation between health outcome and the GDP per capita, adult literacy rate, and outof-pocket expenditure; environmental pollution has a negative relation with health outcomes; and age dependency ratio and public health expenditure also show a positive elasticity with infant mortality rate. Kim and Lane (2013) 
analyzed the relationship between public health expenditure and national health outcomes among developed countries. The findings showed a negative relationship between government health expenditure and infant mortality rate, and a positive relationship between government health expenditure and life expectancy at birth. Jaba, Balana and Robu (2014) analyzed the relationship between the dynamics of the inputs and the outputs of health care systems and found that there is a significant relationship between health expenditures and life expectancy and that country effects are significant and show the existence of important differences among the countries.

In their study on the dynamic analysis of the relationship among health spending, health outcomes and per capita income in Canada, Day and Tousignant (2005) employed the vector autoregression (VAR) model and the generalized impulse response function estimation technique and found evidence of a weak statistically significant relationship between per capita health spending, health outcomes, and per capita GDP. Gani (2009) examined the relationship between per capita public health expenditure and three measures of health outcomes for seven Pacific Island countries. The result provided strong evidence that per capita health expenditure is an important factor in determining health outcomes. The empirical results also provide strong evidence that per capita incomes and immunization are additional core factors that determine health outcomes.

Novignon and Lawanson (2016) sought to understand the relationship between child health outcomes and health spending while investigating lagged effects. The results show a positive and significant relationship between health expenditure and child health outcomes. Public health expenditure was found to be relatively more significant than private expenditure. Novignon, Olakojo and Novignon (2012) employed the fixed and random effects panel data regression model estimation techniques to assess the effect of health care expenditure on population health status and to examine the effect by public and private expenditure sources. The results show that health care expenditure significantly influences health status through improving life expectancy at birth, reducing death and infant mortality rates. Both public and private health care spending showed strong positive association with health status even though public health care spending had relatively higher impact. Edeme, Emecheta and Omeje (2017) investigated the effect of public health expenditure on health outcomes in Nigeria and found that an increase in public health expenditure improves life expectancy and reduces infant mortality rates. Maduka et al. (2016) employed the Toda-Yamamoto causality approach in estimating the nexus amongst health outcomes, health expenditure and growth in Nigeria between 1970 and 2013. The study reveals the existence of long run relationship amongst the variables investigated. Based on the Toda-Yamamoto causality test, it was ascertained that public health expenditure does not lead economic growth directly, but affects it through health outcomes. Nwani and Kelikume (2019) investigate the causal linkages amongst public expenditure on health, health status and economic growth in Nigeria using the Toda-Yamamoto technique. Their finding indicates that public health expenditure, health status and economic growth have long-run association. Further, the Toda-Yamamoto causality test result reveals the absence of causality between health expenditure and health status. Similarly, health status and economic growth are not causally interdependent.

Nwani et al. (2018) investigate the role of public health expenditure, environmental pollution and health outcomes in Nigeria from 1981 to 2017 using the ARDL estimation technique. Their study found that health outcome is driven by public expenditure on health, while pollution deteriorates health status of Nigerians. Matthew, Adegboye and Fasina (2015) adopted the vector error correction model to examine government spending on health and its effect on health outcomes in Nigeria and found that public spending on health has a significant relationship with health outcomes in Nigeria and that environmental factors such as carbon dioxide emissions affects individuals' health. Similarly, Nwanosike, Orji, Okafor and Umesiobi (2015) employed the ordinary least square estimation technique to investigate the implication of malaria incidence and malaria spending on Nigeria health outcomes and found that increase in health expenditure and educational expenditure reduce malaria incidence. Yaqub, Ojapinwa and Yussuff (2013) applied the Ordinary Least Squares and the Two-Stage Least Squares estimation techniques to investigate how the effectiveness of public health expenditure is affected by governance in Nigeria. Their finding revealed that public health expenditure has negative effect on infant mortality and under-5 mortalities when the governance indicators are included. Maduka, Madichie and Ekesiobi (2006) examined the relationship among government health expenditure, health outcomes and economic growth in Nigeria using the Toda and Yamamoto causality approach. The results revealed that government health expenditures indirectly influence economic growth through health outcomes such as mortality rate and life expectancy. In their empirical analysis of the relationship existing among life expectancy, public health spending and economic growth in Nigeria, Ogungbenle, Olawumi and Obasuyi (2013) found that there is no causality between life expectancy and public health spending in Nigeria neither is there causality between life expectancy and economic growth in Nigeria over the years. However, the study confirmed that there is bi-directional causality between public health spending and economic growth in Nigeria. 


\section{Research Methods}

This chapter focuses on theoretical framework, model specification and the analytical technique used for estimating the model of the study towards achieving stated objectives. This chapter also evaluates the models adopted in the study which contains the strength and weakness of such model. This study adopted autoregressive distributive lag approach (ARDL) to examine dynamic relationship between oil receipts (OR), health expenditure (HE) and health quality (HQ). This approach yields consistent estimates of the long -run coefficients that are asymptotically normal, irrespective of whether the underlying variables are I(1) or I(0), (Pesaran and Shin, 1995).

The model can be expressed as;

$$
H Q L Y_{t}=f\left(H E X P_{t}, O R_{t}\right)
$$

Health Quality (HQLY) can be measured by Life Expectancy (LEXPT) and Maternal and Infant Mortality Rate (MIMR). Based on previous theoretical and empirical findings as articulated in the literature, as well as the structure of the Nigerian economy, the life expectancy and infant mortality rate also depend on education expenditure, exchange rate, inflationary rate, dependency ratio and unemployment rate. Equation (1) can be expressed as:

$$
\begin{aligned}
& \text { LEXPT }_{t}=f\left(\mathrm{HEXP}_{t}, \mathrm{ORV}_{t},, \mathrm{CEM}_{t}, \mathrm{POV}_{t}, \mathrm{CORR}_{t}, \mathrm{HCP}_{t}, \mathrm{UEMP}_{t} D E P_{t}\right) \\
& \mathrm{MIMR}_{t}=f\left(\mathrm{HEXP}_{t}, \mathrm{ORV}_{t}, \mathrm{CEM}_{t}, \mathrm{POV}_{t}, \mathrm{CORR}_{t}, \mathrm{HCP}_{t}, U E M P_{t} D E P_{t}\right)
\end{aligned}
$$

The ARDL-ECM equations are expressed in equation (4) and equation (5):

$$
\begin{aligned}
& \Delta L E X P T_{t}=\alpha_{o}+\sum_{i=1}^{k} \alpha_{1 i} \Delta H E X P T_{t-i}+\sum_{i=1}^{k} \alpha_{2 i} \Delta O R V_{t-i}+\sum_{i=1}^{k} \alpha_{3 i} \Delta C E M_{t-i}+\sum_{i=1}^{k} \alpha_{4 i} \Delta P O V_{t-i}+ \\
& \sum_{i=1}^{k} \alpha_{5 i} \Delta C O R R_{t-i}+\sum_{i=1}^{k} \alpha_{6 i} H C P_{t-i}+\sum_{i=1}^{k} \alpha_{7 i} \Delta U E M P_{t-i}+\sum_{i=1}^{k} \alpha_{8 i} \Delta D E P_{t-i}+\beta_{1}\left(\gamma_{1} H E X P_{t-i}+\right. \\
& \left.\gamma_{2} O R V_{t-1}+\gamma_{3} C E M_{t-1}+\gamma_{4} P O V_{t-i}+\gamma_{5} C O R R_{t-i}+\gamma_{6} H C P_{t-i}+\gamma_{7} U M P_{t-i}+\gamma_{8} D E P_{t-i}\right)+ \\
& E C M_{t-1}+e_{i t} \\
& \text { (4) } \\
& \Delta L M I M R_{t}=\alpha_{o}+\sum_{i=1}^{k} \alpha_{1 i} \Delta H E X P_{t-i}+\sum_{i=1}^{k} \alpha_{2 i} \Delta O R V_{t-i}+\sum_{i=1}^{k} \alpha_{3 i} \Delta C E M_{t-i}+\sum_{i=1}^{k} \alpha_{4 i} \Delta P O V_{t-i}+ \\
& \sum_{i=1}^{k} \alpha_{5 i} \Delta \operatorname{CORR}_{t-i}+\sum_{i=1}^{k} \alpha_{6 i} \Delta H C P_{t-i}+\sum_{i=1}^{k} \alpha_{7 i} \Delta U E M P_{t-i}+\sum_{i=1}^{k} \alpha_{8 i} \Delta D E P_{t-i}+\beta_{1}\left(\gamma_{1} H E X P_{t-i}+\right. \\
& \left.\gamma_{2} O_{R V_{t-i}}+\gamma_{3} C E M_{t-i}+\gamma_{4} P_{0 V} V_{t-i}+\gamma_{5} C_{C O R R_{t-i}}+\gamma_{6} H C P_{t-i}+\gamma_{7} U M P_{t-i}+\gamma_{8} D E P_{t-i}\right)+ \\
& E C M_{t-1}+e_{i t}
\end{aligned}
$$

\begin{tabular}{|c|c|c|}
\hline Variables & Measurements & Sources \\
\hline Oil Revenue (ORV) & Oil revenue as a percentage of GDP & WDI \\
\hline Poverty (POV) & $\begin{array}{l}\text { Ratio of household final Consumption } \\
\text { expenditure (in constant } 2005 \text { US dollars) to the } \\
\text { total population }\end{array}$ & WDI \\
\hline Health Expenditure (HEXP) & Government budget on health as $\%$ of total budget & WDI \\
\hline Health Care Prices (HCP) & $\begin{array}{l}\text { A proxy variable was calculated by dividing } \\
\text { health expenditure per person measured in } \\
\text { current prices by health expenditure per person } \\
\text { measured in constant } 2011 \text { prices }\end{array}$ & WDI \\
\hline Life Expectancy (LEXP) & Life Expectancy at birth & WDI \\
\hline $\begin{array}{l}\text { Maternal and Infant } \\
\text { Mortality Rate (MIMR) }\end{array}$ & Maternal and Infant Mortality (per 1,000) & WDI \\
\hline Carbon Emission (CEM) & $\begin{array}{l}\text { Per capita carbon emission measured in million } \\
\text { tons } \mathrm{CO}_{2}\end{array}$ & $\begin{array}{l}\text { BP Statistical Review of } \\
\text { World Energy }\end{array}$ \\
\hline Corruption (CORR) & Corruption Perspective Index & $\begin{array}{l}\text { International Country } \\
\text { Risk Guild (ICRG) }\end{array}$ \\
\hline Dependency Ratio (DEP) & Population (65+)/Population (30-64) & UN population \\
\hline
\end{tabular}

The annual time series data from 1980 to 2018 was obtained from Statistical Bulletin and Annual Report and Statement of Accounts of the Central Bank of Nigeria, World Development Indicator (WDI) as well as International Country Risk Guild (see Table 1).

Table 1: The measurements of variables and sources of data

\section{Empirical Result and Discussion}

The empirical analysis in this study starts with the unit root test to examine the nature of stationarity of the series. This is very important because using a non-stationary series to explain another non-stationary series may generate spurious regressions, thereby yielding biased and inconsistent estimates (see Engle \& Granger, 1987). Kwiatkowski-Phillips-Schmidt-Shin (KPSS) and Dickey-Fuller test statistic using a generalized least squares unit root tests (DF GLS) are performed on the series to determine their order of integration. Results from unit root tests would determine the procedure to be employed to estimate the specified model. For instance, if all series are 
integrated of order 0 , then ordinary least squares procedure (OLS) may be used; in contrast, if series are unit root non-stationary, then OLS would result in a spurious regression.

Although common practice in time series modeling has involved the application of (Augmented) Dickey-Fuller and Phillips-Perron tests to determine whether a series possesses a unit root, improved and efficient tests with much better statistical properties are now Dickey-Fuller test statistic using a generalized least squares (DF GLS). This modified test not only has the best overall performance in terms of small-sample size and power, but also has substantially improved power when an unknown mean or trend is present (Stock, 1994; Elliott et al 1996). The unit root test result in Table 2 shows that the null hypothesis of a unit root cannot be rejected for the level series of some variables using KPSS and DF GLS techniques. However, the null hypothesis of a unit root can be rejected for the first difference of all the series at a $5 \%$ level of significance.

Table 2: Unit Root Test

\begin{tabular}{|l|l|l|l|l|l|l|}
\hline \multicolumn{3}{|l|}{ KPSS } & \multicolumn{2}{l|}{ DF-GLS } & \multicolumn{1}{l|}{ Order } \\
\hline Variable & T-Stat & Prob. & Order & T. Stat & Prob. & (1) \\
\hline HEXP & -0.9873 & 0.4236 & $\mathrm{I}(1)$ & -1.5920 & 0.4219 & $1(1)$ \\
D(HEXP) & -8.5968 & 0.0000 & & -5.0427 & 0.0512 & \\
\hline ORV & -1.2274 & 0.6010 & $\mathrm{I}(1)$ & -2.9779 & 0.0891 & $1(1)$ \\
D(ORV) & -6.0590 & 0.0000 & & -5.8042 & 0.0372 & \\
\hline POV & -0.8447 & 0.7932 & $\mathrm{I}(1)$ & -1.9620 & 0.9511 & $1(1)$ \\
D(POV) & -7.6349 & 0.0000 & & -7.0438 & 0.0000 & \\
\hline INFR & -1.3426 & 0.2699 & $\mathrm{I}(1)$ & -2.9959 & 0.0682 & $1(1)$ \\
D(INFR) & -4.8735 & 0.0000 & & -5.8117 & 0.0019 & \\
\hline DEP & 1.6328 & 0.0329 & $\mathrm{I}(1)$ & -1.8921 & 0.0471 & $1(1)$ \\
D(DEP) & -3.9990 & 0.0041 & & -3.0821 & 0.0032 & \\
\hline MIMR & -2.1820 & 0.0732 & $1(1)$ & -2.0049 & 0.0910 & $1(1)$ \\
D(MIMR) & -8.9302 & 0.0000 & & -8.0418 & 0.0000 & \\
\hline LEXP & -4.0721 & 0.0042 & $1(0)$ & -1.7900 & 0.4911 & $1(1)$ \\
D(LEXP) & & & & -4.5591 & 0.0382 & \\
\hline EDEXP & -1.0753 & 0.6921 & $1(1)$ & -1.8021 & 0.0877 & $1(1)$ \\
D(EDEXP) & -4.7321 & 0.0109 & & 5.9819 & 0.0000 & \\
\hline CORR & -4.8901 & 0.0431 & $1(0)$ & -2.9822 & 0.0927 & $1(1)$ \\
D(CORR) & & & & -7.9319 & 0.0000 & \\
\hline
\end{tabular}

Source: Authors' Compilation (2020) from E-Views 10

Furthermore, pair wise ranger causality was performed to see whether there is a causal relationship between these variables. The direction of causality between oil revenue (ORV), health expenditure (HEXP), life expectancy (LEXP), and maternal and infant mortality rate (MIMR) is depicted in Table 3. The result shows that the null hypothesis that states that oil revenue (ORV) does not Granger Cause health expenditure (HEXP) is rejected given the p-value which is below 5\%, however, the null hypothesis that health expenditure (HEXP) does not Granger Cause oil revenue (ORV) is accepted which is statistically insignificant at $5 \%$. It implies that a unidirectional causal relationship exists between oil revenue and heath expenditure with causality running from oil revenue to health expenditure. Furthermore, it was also revealed that a unidirectional causal relationship exists between oil revenue (ORV) and maternal and infant mortality rate (MIMR). Thus, given the result, this study rejects the null hypothesis that states that there is no causal relationship between oil revenue (ORV) and health expenditure in Nigeria. This result shows that unidirectional causality run from oil revenue to health expenditure and from oil revenue (ORV) to maternal and infant mortality rate (MIMR). No causal relationship was observed between oil revenue and life expectancy. Also, bi-directional causal relationship was observed between health expenditure and maternal and infant mortality rate in Nigeria. This contradicts the finding of Ogungbenle et al (2013), Nwani and Kelikume (2019) which revealed no causal relationship between health expenditure and life expectancy. 


Table 3: Granger Causality Result
\begin{tabular}{|l|c|r|}
\hline Pairwise Granger Causality Tests & F-Statistic & Prob. \\
\hline Null Hypothesis: & 3.95612 & $0.0307^{*}$ \\
\hline ORV does not Granger Cause HEXP & 5.70030 & 0.1784 \\
\hline HEXP does not Granger Cause ORV & 2.13549 & $0.0279^{*}$ \\
\hline ORV does not Granger Cause MIMR & 3.86123 & 0.5830 \\
\hline M IMR does not Granger Cause ORV & 4.21213 & 0.1252 \\
\hline ORV does not Granger Cause LEXP & 0.56438 & 0.5750 \\
\hline LEXP does not Granger Cause ORV & 3.73431 & $0.0365^{*}$ \\
\hline HEXP does not Granger Cause MIMR & 6.74165 & $0.0041^{*}$ \\
\hline IMR does not Granger Cause HEXP & 3.73431 & $0.0491^{*}$ \\
\hline HEXP does not Granger Cause LEXP & 4.21213 & $0.017^{*}$ \\
\hline LEXP does not Granger Cause HEXP & Note: * Rejection of null hypothesis at 5\% \\
Source: Author's compilation
\end{tabular}

\subsection{Short Run Dynamics}

This study having established the presence of a long relationship among oil revenue, health expenditure and health quality in Nigeria, the short dynamics was tested using the Error Correction Model (ECM) and the result shown in Table 4. The error correction term (ECT) is well signed and statistically significant at 5 percent, which implies that a deviation from long run equilibrium is restored by approximately $51 \%$ and $58 \%$ each year in model A and model B respectively. The coefficient of oil revenue shows insignificant effect on mortality rate and life expectancy in the short run. This implies the impact of oil revenues on health quality is not significant in the shortrun. Health expenditure is significant in explaining health quality though the impact is mild. A percentage change in allocation to health sector reduce maternal and infant mortality rate by just $0.031 \%$ and increase life expectancy by $0.049 \%$. The coefficient of corruption is significant with right sign in explaining health quality in Nigeria. This result shows that institutional quality must be strengthened for the sustainable developmental goal of quality health services to be realized.

Table 4: Short run ECM Model for Health Quality (HQLTY)

\begin{tabular}{|l|l|l|l|l|l|c|}
\hline & \multicolumn{5}{|l}{ Model A: MIMR } & Model B: LEXP \\
\hline Variables & Coefficient & t-statistics & Prob. & Coefficient & t-statistics & Prob. \\
\hline DORV & 0.0221 & -1.7178 & 0.1821 & 0.0729 & -1.9902 & 0.1617 \\
\hline DHEXP & $-0.0031^{* *}$ & 3.0626 & 0.0409 & $0.0049^{*}$ & 5.0189 & 0.0000 \\
\hline DCORR & $0.6056^{*}$ & 3.7290 & 0.0000 & $0.4918^{*}$ & 2.9511 & 0.0391 \\
\hline ECM & -0.5105 & 2.7116 & 0.0519 & $-0.5809^{* *}$ & 2.8710 & 0.0491 \\
\hline
\end{tabular}
respectively.

\subsection{Long Run Results}

The results of the co-integration test based on the ARDL-bounds testing method are presented in Table 5. The results in Model A (Maternal and infant mortality rate) and B (Life expectancy) indicate that the F-statistic is greater than the upper critical bound from Pesaran et al. (2001) at 5\% significance level using restricted intercept and no trend. This study therefore rejects the null hypothesis of no cointegration among the variables. This shows that there is a long-run causal relationship among these variables in Nigeria. F-test results indicate that we reject the null hypothesis of no cointegration between variables, since computed value of F-statistics in Model A (6.381) and Model B (5.717) are greater than I(1) bound value at 5\% level of significance. Thus, we conclude that the variables are cointegrated which implies that there is a long-run relationship among them. 
Table 5: Cointegration Result

\begin{tabular}{|l|c|c|}
\hline & Model A & Model B \\
\hline Bound F- Statistics & 6.381 & 5.717 \\
\hline Critical Bounds & $5 \%$ & $5 \%$ \\
\hline I $(0)$ & $\mathbf{2 . 4 5}$ & $\mathbf{3 . 9 3}$ \\
\hline I(I) & $\mathbf{3 . 6 1}$ & $\mathbf{5 . 2 1}$ \\
\hline
\end{tabular}

Critical bound from Pesaran et al. (2001)

The bounds test result shows that there exists cointegration because the bounds F-statistics value is greater than the $\mathrm{I}(0)$ and $\mathrm{I}(1)$ series, the study then proceeds to present both the short run and long run result for the models. Table 6 presents the long-run coefficients using ARDL approach. The estimated oil revenue has a negative and significant impact on maternal and infant mortality rates in the long run. The results further indicate that for every 1 percent positive change in oil revenue, maternal and infant mortality rate reduces by 0.191 percent in the long run. Health expenditure has negative and significant impact on maternal and infant mortality rate in the long run. This is consistence with the findings of Yaqub et al (2013), Maduka et al. (2006), Becchetti, et al (2017) and Ramu (2015).

Poverty has negative and significant impact on maternal and infant mortality rate in both the short -run and longrun. This result agrees with the findings of Gertler, et al. (2011), Sa'ad and Bugaje (2016). Thus, a 1\% increase in poverty rate brings about a $0.14 \%$ rise in maternal mortality rate. They affirmed the synergistic interrelationships that exist between poverty and maternal mortality, especially in developing countries. The implication of this is that government should adopt a comprehensive policy framework for reducing the rising and alarming level of poverty estimated at $33.1 \%$ (World Bank, 2011) if the crusade to reduce the maternal mortality rate to an acceptable level in Africa's biggest economy is to be realized. Thus, within the Nigerian context, policies directed at alleviating poverty have the potential of producing a significant net decrease in the nation's maternal mortality ratio. This result is corroborated by those of Demery and Walton (1998), Alvarez, Gil, Hernandez and Gil (2009), Umoru and Yaqub (2013) and Kim and Lane (2013). The coefficient of health care price shows positive and significant impact on mortality rate. This is consistence with theoretical postulation that there is inverse relationship between health care price and health quality. The coefficient of corruption, dependent ratio, unemployment and carbon emission are significant with right signs in explaining health quality in Nigeria.

Model B (Life expectancy) shows that oil receipt has positive and significant impact on life expectancy in the long run. Also, the coefficient of government expenditure on health has positive and significant impact on life expectancy in the long-run which is in line with our a priori expectation. This finding corroborates results from earlier studies by Edeme, Emecheta and Omeje (2017), Olakojo and Novignon (2012), Novignon and Lawanson (2016). They affirmed the synergistic relationships that exist between health expenditure and health outcome in Nigeria. The coefficient of poverty is negative and significant on life expectancy. The result revealed that a unit increase in poverty reduces life expectancy in the long run. This result showed that poverty is one of the contributors to premature death in Nigeria. Corruption has negative and significant impact on life expectancy in both short-run and long-run. There is inverse relationship between corruption and life expectancy.

The diagnostic test for the coefficient of the Jaque- Bera statistics suggests that the test for the residual normality assumption was adequate and as such not violated, that is the Jaque-Bera indicates that the study cannot reject the null hypothesis that the true error terms in the variables are normally distributed when judging through the probability value, this in essence indicates that the functional normality of the ARDL model is appropriate for the study. The coefficient of the Breush -Godfrey LM statistics conforms to the absence of serial correlation. Similarly, the probability values of the heteroscedasticity test show that the variance is not time-dependent which implies it is homoscedastic. The statistical properties of the models as indicated by the diagnostic probability value show that the models are consistent, efficient and feasible for forecast and policy making. Also, it implying that the coefficients seem to follow a stable pattern during the estimation period; thus, one can use these coefficients for policy decision-making purposes since the model do not suffer from any structural instability over the period of study. 
Table 6: Long run estimates for Health Quality

\begin{tabular}{|c|c|c|c|c|c|c|c|}
\hline & \multicolumn{4}{|c|}{ Model A: MIMR } & \multicolumn{3}{|c|}{ Model B: LEXP } \\
\hline Variables & \multicolumn{2}{|c|}{ Coefficient } & t-statistics & Prob. & Coefficient & t-statistics & Prob. \\
\hline Constant & \multicolumn{2}{|c|}{$-0.0112 * *$} & -2.6311 & 0.0419 & $-0.3301 * * *$ & -2.9018 & 0.0501 \\
\hline ORV & \multicolumn{2}{|c|}{$-0.0321 * * *$} & -2.0178 & 0.0821 & $0.8021 * * *$ & -2.2902 & 0.0617 \\
\hline HEXP & \multicolumn{2}{|c|}{$-0.0919 * *$} & -2.9626 & 0.0409 & $0.0729 *$ & 5.0189 & 0.0000 \\
\hline POV & \multicolumn{2}{|c|}{$0.1412 * *$} & 2.7116 & 0.0519 & $-0.1809 * *$ & -2.8710 & 0.0491 \\
\hline CEM & \multicolumn{2}{|c|}{$0.1182 *$} & 3.6015 & 0.0000 & $-1.1903 * * *$ & -2.0189 & 0.0821 \\
\hline UEMP & \multicolumn{2}{|c|}{$0.9027 * *$} & 3.0189 & 0.0488 & $-0.6952^{*}$ & -3.9186 & 0.0273 \\
\hline $\mathrm{HCP}$ & \multicolumn{2}{|c|}{$1.0539 * * *$} & 2.0923 & 0.0891 & $-0.9172 * *$ & -2.9011 & 0.0319 \\
\hline DEP & \multicolumn{2}{|c|}{$0.0912 * * *$} & 2.0131 & 0.0911 & $-0.4430 *$ & -5.0219 & 0.0000 \\
\hline CORR & 0.11 & & 5.9015 & 0.0000 & $-0.5782 * *$ & -2.791 & 0.0318 \\
\hline $\mathrm{R}^{2}$ & \multicolumn{4}{|c|}{0.731} & \multicolumn{3}{|l|}{0.693} \\
\hline F. Statistics & \multicolumn{4}{|c|}{$4.318(0.000)$} & \multicolumn{3}{|l|}{$3.721(0.000)$} \\
\hline \multicolumn{8}{|c|}{ Diagnostic Tests } \\
\hline & & \multicolumn{3}{|c|}{ F-Value (Probability) } & \multicolumn{3}{|c|}{ F-Value (Probability) } \\
\hline \multicolumn{2}{|c|}{ Serial Correlation } & \multicolumn{3}{|c|}{$1.7931(0.6402)$} & \multicolumn{3}{|c|}{$1.7553(0.1210)$} \\
\hline \multicolumn{2}{|c|}{ Functional form } & \multicolumn{3}{|c|}{$0.9317(0.7211)$} & \multicolumn{3}{|c|}{$0.9755(0.5821)$} \\
\hline \multicolumn{2}{|l|}{ Normality } & \multicolumn{3}{|c|}{$1.6882(0.5822)$} & \multicolumn{3}{|c|}{$1.7629(0.6833)$} \\
\hline \multicolumn{2}{|c|}{ Heteroscedasticity } & \multicolumn{3}{|c|}{$1.8550(0.5721)$} & \multicolumn{3}{|c|}{$1.8853(0.7411)$} \\
\hline
\end{tabular}
respectively.

\section{Conclusion and Policy Recommendation}

Health quality has always remained a topical issue among academia and researchers due to lack of consensus on this subject. A potential unresolved issue is not only the causal relationship among the variables but also the effect of oil receipts, health expenditure and health quality. The present study has been an attempt to explore interlinks between these variables. ARDL bound cointegration approach on time series data spanning 1980 to 2018 was utilized. The result shows that unidirectional causality runs from oil revenue to health expenditure, oil revenue (ORV) to maternal and infant mortality rate (MIMR). Also, bi-directional causal relationship was observed between health expenditure and maternal and infant mortality rate in Nigeria. The estimated model also shows that oil revenue has a negative and significant impact on maternal and infant mortality rates and significant positive impact on life expectancy. Also, health expenditure has negative and significant impact on maternal and infant mortality rate. However, it has positive and significant impact on life expectancy. On the basis of the findings, this study concludes that there is need to increase oil fiscal allocation to health sector to improve health quality in Nigeria.

\section{REFERENCES}

Abbas, F. and Hiemenz, U. (2011). Determinants of Public Health expenditures in Pakistan. ZEF- Discussion Papers on Development Policy No. 158, Center for Development Research, Bonn, November 2011.

Ahmad, A.H., Masan, S. (2015), Dynamic relationship between oil revenue, government spending and economic growth in Oman. International Journal of Business and Economic Development, 3(2), 93-115.

Akinlo, A.E. (2012). How important is Oil in Nigeria's Economic Growth? Journal of Sustainable Development. 5(4) p 165-179.

Agbatogun, K.K and Taiwo, A.S (2010). Determinants of Health Expenditure in Nigeria. Journal of Research in National Development, 8(2): 1-9.

Almulali, U., Che, S.C.N. (2013), Exploring the impact of oil revenues on OPEC members macroeconomy. Energy Review, 37(4), 416-428.

Aregbeyen, O., Kolawole, B.O. (2015), Oil revenue, public spending and economic growth relationships in Nigeria. Journal of Sustainable Development, 8(3), 113.

Barro, R.J. (1974), Are government bonds net wealth? Journal of Political Economy, 82(6), 1095-1117.

Babatunde, M. A. (2012). An analysis of the Growth - Health Relationship in Nigeria - A paper presented at the Center for the Study of Africa Economic Development, Dakar, Senegal. 
Buchanan, J.M., Wagner, R.W., (1978), Dialogues concerning fiscal religion. Journal of Monetary Economics, 4, 627-636.

Becchetti, L., Conzo, P., and Salustri, F. (2017), The Impact of Health Expenditures on the Number of Chronic Diseases. Health Policy 121(9) 670-83

Boachie, M. K \& Ramu, K., (2015) Public Health Expenditures and Health Status in Ghana MPRA Paper 66371, University Library of Munich, Germany.

Day K. and Tousignant J. (2005). Health Spending, Health Outcomes and Per Capita Income in Canada: A Dynamic Analysis. Department of Finance Working Paper 2005-07.

Dickey, D., Fuller, W. (1979), Distribution of the estimators for autoregressive time series with a unit root. Journal of the American Statistical Association, 74(366), 427-431.

Dizaji, S.F. (2014), The effects of oil shocks on government expenditures and government revenues nexus (with an application to Iran's sanctions). Economic Modelling, 40, 299-313.

Elola J., Daponte A. and Navarro V. (1995). Health indicators and the Organization of Health Care Systems in Western Europe. American Journal of Public Health, 85(10), 1397-1401

Ebrahim, E., Mohammad, A.A. (2012), Asymmetric impacts of oil prices and revenues fluctuation on selected macroeconomic variables in Iran. Journal of Basic and Applied Scientific Research, 2(8), 7930-7937.

Edeme R. K, C Emecheta, M. O. Omeje (2017). Public health expenditure and health outcomes in Nigeria. American Journal of Biomedical and Life Sciences. 2017;5(5): 96-102.

Elliot, G, Rotherbery, T.J., and Stock, J.H (1996) Efficient Tests for an Autoregressive Unit Root, Econometrica, 64(4) 813-836

Eltony, M.N., Al-Awadi, M. (2001), Oil price fluctuations and their impact on the macroeconomic variables of Kuwait: A case study using a VAR model. International Journal of Energy Research, 25, 938-959.

Engle, R.F., Granger, C.W.J. (1987), Co-integration and error correction: Representation, estimation and testing. Econometrica, 55(2), 251-276.

Farzanegan, M., Markwardt, G. (2009), The effect of oil price shocks on the Iranian economy. Energy Economics, $31,134-151$.

Gani A (2009). Health Care Financing and Health Outcomes in Pacific Island Countries. Heal Pol Plann. 24:7281 .

Gertler, P., Shelef, O., Wolfram, C., and Fuchs, A, (2011)." Poverty, Growth and the Demand for Energy”.Energy Institute at Haas, EI@Haas WP 224.

Granger, C.W.J. (1969), Investigating causal relations by econometric models and cross spectral methods. Econometrica, 37, 424-35.

Hamdi, H., Sbia, R. (2013), Dynamic relationships between oil revenues, government spending and economic growth in an oil-dependent economy, Economic Modelling, 35, 118-125.

Iwayemi, A. (2001) Nigeria's Fractured Development: The Energy Connection. University of Ibadan Inaugural Lecture Series, Ibadan.

Jaba E., Balana C.B. and Robu I. (2014). The Relationship Between Life Expectancy at Birth and Health Expenditures Estimated by a Cross-Country and Time-Series Analysis. Procedia Economics and Finance 15, $108-114$.

Kamiya, Y. (2010) Determinants of Health in Developing Countries: Cross-Country Evidence. OSIPP Discussion Paper: DP-2010-E-009:

Kim T.K. and Lane S.R. (2013). Government Health Expenditure and Public Health Outcomes: A Comparative Study among 17 Countries and Implications for US Health Care Reform. American International Journal of Contemporary Research 3(9).

Kulkarni L. (2016). Health Inputs, Health Outcomes and Public Health Expenditure: Evidence from the BRICS Countries. International Journal of Applied Economics, 31(1), 7284. 
Lorde, T., Jackman, M., Thomas, C. (2009), The macroeconomic effects of oil price fluctuation on a small open oil-producing country: The case of Trinidad and Tobago. Energy Policy, 37, 2708-2716.

Matthew, O.A Adegboye, F.B and Fasina, F. F. (2015), Public Health Expenditure and Health Outcomes in Nigeria. International Journal of Financial Economics, 4(1), 45-56.

Maduka Anne C, Madichie C, Ekesiobi C (2016). Health care expenditure, health outcomes and economic growth nexus in Nigeria: A Toda - Yamamoto Causality Approach. Unified Journal of Economics and International Finance. 2016;2(1):1-10.

Mekdem M (2012), Study of the relation between health and economic growth: Empirical Validation from a panel of 15 countries of the North and South Bank Mediterranean. Interdisciplinary Journal of Contemporary Research in Business, 4(1).175-186.

Mohsen M \& Maysam M (2011), Granger causality between Health and Economic Growth in Oil Exporting Countries, Interdisciplinary Journal of Research in Business 1(8), 103-108

Novignon J, Olakojo SA, Nonvignon J. (2012), The Effects of Public and Private Health Care Expenditure on Health Status in sub-Saharan Africa: New Evidence from Panel Data Analysis. Health Economics Review. $2: 22$.

Novignon J, Lawanson A. O. (2017). Health Expenditure and Child Health Outcomes in sub-Saharan Africa. African review of Economics and Finance. 9:1.

Nwanosike C.U., Orji A., Okafor J.C. and Umesiobi C. (2015). Progressive Health Spending and Health Outcomes in Nigeria: The Case of Malaria. International Journal of Academic Research in Business and Social Sciences, 5(12).

Nwani1 and Kelikume (2019), Causal Linkage amongst Public Expenditure on Health, Health Status and Growth: New Empirical Evidence from Toda-Yamamoto Approach for Nigeria. Journal of Scientific Research \& Reports, 24(3): 1-13.

Nwani Stanley Emife, Fatai Adeshina Kelani, Azuka Elvis Ozegbe, Oluleye H. Babatund (2018). Public health expenditures, environmental pollution and health outcomes: Evidence from Nigeria. South Asian Journal of Social Studies and Economics. 2018;1-15

Odubunmi AS, Saka JO, Oke D. M (2012). Testing the co-integrating relationship between healthcare expenditure and economic growth in Nigeria. International Journal of Economics and Finance. 2012;4(11):99107.

Olaniyan, O., Onisanwa, I.D and Oyinlola, A (2013). Health Care Expenditures and GDP in sub-Saharan African Countries: Evidence from Panel Data. Paper submitted for presentation at the 2013 Centre for the Study of African Economies Conference on Economic Development in Africa held at St Catherine's College, Oxford, 17-19 March 2013

Olomola, P. A. \& Adejumo, A.V. (2006). Oil Price Shock and Macroeconomic Activities in Nigeria. International Research Journal of Finance and Economics, Issue 3

Ogungbenle, S.,Olawuyi, and Obasuyi, O (2013), Health Expenditure, Health Outcomes and Economic Growth. European Scientific Journal 9(19) 1857-7881

Sa'ad, S., Bugaje, I.M. (2016), Biomass Consumption in Nigeria: Trends and Policy Issues. Journal of Agriculture and Sustainability, 9(2), 127-157.

Stock, J. H. and Watson, M. W. (1993) A simple estimator of cointegrating vectors in higher order integrated systems, Econometrica, 61, 783-820.

Tang, C. F (2010). The determinants of Health Expenditure in Malaysia: A time Series Analysis. Munich Personal REPEc Archive, Paper No .24356.

Yaqub, Ojapinwa and Yussuff (2013), Public Health Expenditure and Health Outcomes, European Scientific Journal, 8(13): 189-201 